\title{
Pengaruh Penerapan Quantum Teaching Terhadap Peningkatan Keterampilan Tata Boga Anak Tunagrahita Ringan
}

\author{
Yuliati Ningsih ${ }^{1}$, Jon Efendi ${ }^{2}$, Marlina Marlina ${ }^{3}$ \\ ${ }^{123}$ Universitas Negeri Padang, Indonesia \\ Email: yuliatiningsih17juli@gmail.com
}

\section{INFORMASI ARTIKEL}

Terkirim 02 Februari 2019

Revisi 17 September 2019

Diterima 07 Maret 2020

Kata kunci:

pendekatan quantum

teaching, anak tunagrahita

ringan

\begin{abstract}
ABSTRAK
Permasalahan yang ditemukan di SLBN 1 Padang pada anak tunagrahita ringan kelas tata boga dilatar belakangi oleh guru menggunakan metode ceramah, tanya jawab, dan latihan dalam pembelajaran keterampilan tata boga dengan penugasan secara individual. Selain itu, kemampuan siswa yang bervariasi mengakibatkan siswa mengalami kesulitan membuat puding pisang. Penelitian ini menggunakan metode Penelitian Tindakan Kelas, subjek penelitian terdiri dari guru kelas dan 4 orang anak tunagrahita ringan. Siklus yang dilaksanakan dalam beberapa tahap yaitu perencanaan, pelaksanaan tindakan, observasi dan refleksi. Data dikumpulkan dengan cara observasi, studi dokumentasi dan tes. Hasil menunjukkan bahwa proses dan hasil keterampilan pembuatan puding pisang anak tunagrahita ringan kelas tata boga meningkat melalui pendekatan quantum teaching. Dapat disimpulkan bahwa, pelaksanaan pembelajaran keterampilan tata boga melalui pendekatan quantum teaching dapat meningkatkan keterampilan proses pembuatan puding pisang.
\end{abstract}

\footnotetext{
(c) (i) (2)

This is an open access article distributed under the Creative Commons 4.0 Attribution License, This license lets others remix, tweak, and build upon your work even for commercial purposes, as long as they credit you and license their new creations under the identical terms $\odot 2018$ by author and Universitas Negeri Padang.
}

\section{Pendahuluan}

Pendidikan untuk siswa tunagrahita memiliki spesifikasi tersendiri, karena fungsi intektualnya yang mengalami keterbatasan, maka pengembangannya diarahkan pada potensi lain diantaranya potensi skill atau keterampilannya. Keterampilan merupakan salah satu usaha memberikan bantuan kepada peserta didik untuk mengembangkan diri dalam mencapai kemandirian. Melalui keterampilan diharapkan akan membantu anak tunagrahita untuk mampu berkarya ditengah-tengah masyarakat untuk memenuhi kebutuhan hidupnya. Akibat jika anak tunagrahita tidak di beri pembelajaran keterampilan maka anak akan memiliki ketergantungan kepada orang lain semasa hidupnya. Untuk itu di diberikan beberapa keterampilan diantaranya keterampilan tata boga, keterampilan tata busana, keterampilan salon/kecantikan, keterampilan musik. Keterampilan tata boga bermanfaat dalam kehidupan sehari-hari, karena dengan keterampilan tata boga siswa tahu berbagai macam masakan, kue-kuean, berbagai macam minuman dan lain-lain yang bisa dikembangkan dalam kehidupan sehari-hari juga sebagai dasar keterampilan untuk menunjang kehidupan.

Hasil pengamatan awal di SLBN 1 Padang pada bulan Februari-Maret 2017, diperoleh informasi anak sedang melakukan proses pembuatan puding pisang, terlihat beberapa anak yang tidak melakukan langkah-langkah sesuai dengan perintah guru. Kerena keterbatasan waktu dalam pembelajaran maka guru kesulitan memberikan pengajaran yang lebih terperinci kepada anak. Hasil wawancara dengan guru bahwa anak pada kelas keterampilan tata boga terdapat empat orang siswa dan siswi, dari keempat orang siswa dan siswi tersebut memiliki tingkat kemampuan yang berbeda-beda. Berdasarkan informasi yang didapat dari guru keterampilan tata boga di sekolah tersebut, sekolah telah memiliki alat dan bahan, yang lengkap dikelas tata boga.

Sosok guru dikelas wajib memiliki sikap guru kompetensi profesional serta sikap kompetensi dan karakter yang baik. Oleh karena itu, para guru anak kebutuhan khusus diperlukan untuk memiliki kopetensi yang handal. Kompetensi ini adalah kompetensi teknis dan kolaboratif (Zulfijja, et al, 2013 : Yusuf, 1999 dalam Marlina). Westwood menjelaskan kompetensi teknis yang meliputi: Kompetensi Guru dalam memahami berbagai teori tentang anak - anak dengan kebutuhan khusus, memahami berbagai tes yang berhubungan dengan Pendidikan Khusus, terampil dalam melakukan penilaian dan evaluasi, terampil dalam mengajar berbicara, menulis, membaca, matematika, manajemen perilaku dan terampil dalam 
memberikan pra-kejuruan dan pelajaran kejuruan. Sementara kompetensi kolaboratif konsultasi adalah kemampuan untuk bekerja sama dengan berbagai pihak terkait.

Banyak metode pembelajaran yang dilakukan oleh guru di kelas tata boga metode yang digunakan guru yaitu dengan metode ceramah, dan latihan. Metode yang dipakai guru tersebut memeliki beberapa kelemahan, bila terlalu lama menggunakan metode ceramah membosankan anak, sukar mengontrol sejauh mana pemerolehan belajar anak didik dan menyebabkan anak didik pasif (Jumanta Hamdayana, 2016:99). Sedangkan pada penerapan metode latihan memilik kelemahan menghambat bakat dan inisiatif anak didik karena anak didik lebih banyak dibawa pada penyesuaian, serta diarahkan jauh, latihan yang dilakukan secara berulang-ulang merupakan hal yang monoton dan mudah membosankan (Jumanta Hamdayana, 2016:104). Guru menginformasikan bahwa anak telah diajarkan cara membuat puding pisang. Namun hasil proses pembuatan puding pisang belum maksimal, dikarenakan anak belum memahami bahan dan langkah pembuatan puding pisang sehingga nilai yang diperoleh anak tidak mencapai kriteria ketuntasan minimal (KKM).

Peneliti melakukan penelitian menggunakan pendekatan quantum teaching sebagai salah satu alternatif. Quantum teaching menciptakan lingkungan belajar yang efektif dengan cara menggunakan unsur yang ada pada siswa dan lingkungan belajarnya melalui interaksi yang terjadi di dalam kelas (Eveline Siregar, 2011:82). Pembelajaran keterampilan tata boga di SLB, mempunyai tujuan pembelajaran peserta didik diharapkan dapat : mengenal beberapa alat dan komponen pelengkap materi dari pembelajaran tata boga, mengenal beberapa resep kuliner Nusantara orientaal dan continental, mengenal perhitungan harga, mengenal teknik pemasaran, mengenal konsep berwirausaha (Departemen Pendidikan Nasional, 2006:6).

Quantum teaching dapat didefenisikan sebagai pengubahan belajar yang meriah, dengan segala nuansa (Bobbi DePorter, 2014:32). Ada istilah mengatakan bahwa "Bawalah dunia mereka ke dunia kita, dan hantarkanlah dunia kita ke dunia mereka" hal ini menunjukkan, betapa pengajaran dengan quantum teaching tidak hanya menawarkan materi yang mesti dipelajari siswa tetapi jauh dari itu, siswa juga diajarkan bagaimana menciptakan hubungan emosional yang baik ketika belajar (Eveline Siregar, 2014:82).

Pembelajaran quantum teaching mengutamakan keberagaman dan kebebasan, bukan keseragaman dan ketertiban. Keberagaman dan kebebasan dikatakan sebagai kata kunci selain interaksi. Pembelajaran quantum teaching berkembang ucapan : selamat datang keberagaman dan kebebasan, selamat tinggal keseragaman dan ketertiban. Di sinilah perlunya diakui keragaman gaya belajar siswa, dikembangkan aktivitas-aktivitas pembelajaran yang beragam (Jumata Hamdayana, 2014:75). Quantum teaching memiliki lima prinsip yang mempengaruhi seluruh aspek quantum teaching. Prinsip-prinsip pendekatan quantum teaching meliputi (1) segalanya berbicara .Lingkungan kelas, bahasa tubuh, dan bahan pelajaran semuanya menyampaikan pesan tentang belajar. (2) Segalanya bertujuan. Siswa diberitahu apa tujuan mereka mempelajari materi yang kita ajarkan. (3) Pengalaman sebelum pemberian nama. Proses belajar paling baik ketika siswa telah mengalami informasi sebelum mereka memperoleh nama untuk apa yang mereka pelajari. (4) Akui setiap usaha Menghargai usaha siswa sekecil apapun. (5) Jika layak dipelajari, layak pula dirayakan. Kita harus memberi pujian pada siswa yang terlibat aktif pada pelajaran kita. Misalnya saja dengan memberi tepuk tangan, berkata : bagus, dan lain-lain.

Kerangka rancangan pembelajaran menggunakan pendekatan quantum teaching dikenal dengan singkatan "TANDUR" yang merupakan akronim dari : Tumbuhkan, Alami, Namai, Demonstrasikan, Ulangi, dan Rayakan. Tumbuhkan : sertakan diri mereka, pikat mereka, pusatkan keingintahuan mereka. Alami : berikan mereka pengalaman belajar, tumbuhkan "kebutuhan untuk mengetahui", Namai : berikan "data" tepat saat minat memuncak mengenalkan konsep-konsep pokok dari materi pembelajaran. Demonstrasikan : sediakan kesempatan mereka untuk menunjukkan bahwa mereka tahu. Ulangi : tunjukkan kepada mereka cara-cara mengulang materi dan menegaskannya. Rayakan : ingat, jika layak dipelajari, maka layak pula dirayakan (Jumata Hamdayana, 2014:76).

Berdasarkan deskripsi tersebut, maka masalah yang harus dijawab dalam artikel ini adalah sebagai berikut : (1) Bagaimana proses meningkatkan ketermpilan pembuatan puding pisang melalui pendekatan quantum teaching bagi anak tunagrahita ringan kelas tata boga di SLB N 1 Padang? (2) Apakah keterampilan proses pembuatan puding pisang pada anak tunagrahita ringan dapat ditingkatkan dengan menggunakan pendekatan quantum teaching di SLB N 1 Padang?

\section{Metode \\ Jenis Penelitian}

Penelitian ini menggunakan metode Penelitian Tindakan Kelas (PTK) atau Classroom Action Reaseach (CAR). penelitian tindakan kelas merupakan sebuah proses pengamatan terhadap kegiatan pembelajaran yang dilakukan oleh guru itu sendiri untuk memperbaiki kualitas pembelajaran dan meningkatkan hasil belajar siswa Jasman, Jalil (2014:6). penelitian tindakan kelas adalah penelitian tindakan yang dilakukan oleh guru dengan tujuan memperbaiki mutu praktik pembelajaran dikelasnya Suharjono (2016:124). Penelitian tindakan kelas terdiri dari 2 siklus, siklus I berfokus kepada proses pembuatan puding pisang. Siklus II melanjutkan siklus I tetapi disertai dengan langkah-langkah menghias pudding pisang. 


\section{Subjek Penelitian}

Subjek penelitian adalah guru kelas tata boga bernama Novry Wahyuni beserta 4 orang anak tunagrahita ringan di kelas tata boga di SLB N 1 Padang. Terlihat anak mengalami kesulitan ketika proses pembuatan puding pisang, penelitian dilakukan di kelas tata boga, serta anak yang menjadi responden tersebut berjumlah 4 orang anak yakni berinisial DM, DA IS, N. Penelitian dilakukan dengan bentuk kolaborasi dengan guru kelas yaitu guru kelas sebagai pengamat dan peneliti bertindak sebagai pemberi tindakan. Antara guru kelas dan pengamat juga berkolaborasi dalam perumusan masalah sampai pada pelaporan hasil penelitian. Penelitian menggunakan siklus, dimana dalam tiap siklus konsep pokok action research terdiri dari empat komponen, terdiri dari perencanaan, tindakan, pengamatan dan refleksi (Kunandar, 2012:70).

\section{Teknik Pengumpulan Data}

Pengumpulan data dapat dilakukan dengan menggunakan beberapa teknik pengumpulan data. Teknik pengumpul data yang tepat dan benar, sangat memberikan data yang objektif, teknik pengumpulan data yang sering digunakan adalah observasi merupakan pengamatan seberapa jauh tindakan mencapai sasaran observasi dapat dilakukan dengan berpedoman kepada cacatan lapangan, observasi aktivitas dikelas, penggambaran interaksi didalam kelas. Cacatan lapangan sebagai alat wujud dari pengamatan dapat digunakan untuk mencatat data kualitatif, kasus istimewa, atau untuk melukis suatu proses. Terkait dengan hal di atas, teknik pengumpulan data ini dalam bentuk observasi. Observasi ini dilakukan untuk guru dan siswa, sebagai pengamat dan menilai bagaimana proses guru memberi materi terkait dengan penelitian ini dan memberi penilaian berdasarkan instrumen observasi. Berdasarkan instrumen observasi, peneliti membuat instrumen ini berdasarkan instrumen penilaian pelaksanaan pembelajaran (RPP) pendidikan dan memodifikasi Instrumen Penilaian Pelaksanaan. Wawancara. Studi dokumentasi Dalam penelitian ini peneliti juga mengunakan studi yang berbentuk photo dan vidio, yang bertujuan untuk mempelajari data dan memperoleh informasi tentang proses pembuatan puding pisang. Dokumentasi dilakukan setiap pembelajaran pembuatan puding pisang dengan menerapkan pendekatan quantum teaching. Tes digunakan untuk mengukur ada atau tidaknya serta besarnya kemampuan objek yang diteliti (Arikunto, 2013: 266). Tes bisa dilakukan secara lisan, tulisan dan perbuatan. Dalam penelitian ini, tes yang digunakan untuk mendapatkan data adalah dengan menggunakan tes lisan dan tes perbuatan. Tes lisan dengan cara menyebutkan bahan-bahan pembuatan puding pisang. Sedangkan, tes perbuatannya adalah dengan melakukan praktek langsung proses pembuatan puding pisang. (Iskandar, $2011: 68$ ).

\section{Teknik Analisis Data}

Analisis data penelitian Untuk memperoleh kebenaran hasil penelitian dapat menempuh langkah-langkah, seperti dikemukakan oleh Sugiyono (2013:174): 1. Reduksi data, data yang diperoleh dari lapangan jumlahnya cukup banyak untuk itu perlu dicatat secara teliti dan perlu segera dilakukan analisis data melalui reduksi data. Analisis ini dilakukan dengan cara mengumpulkan data berulang-ulang lalu dianalisis. Semua data yang telah disimpulkan tersebut tetap menggambarkan proses pelaksanaan pembuatan puding pisang melalui pendekatan quantum teaching. 2. Melakukan display data setelah melakukan reduksi data, langkah selanjutnya adalah mendisplay data, hal ini akan mempermudah untuk memahami apa yang terjadi, dan merencanakan kerja selanjutnya berdasarkan apa yang telah difahami dibuat dalam bentuk pendeskripsian. Pendeskripsian ini dapat dibuat dalam bentuk narasi maupun grafik, menggambarkan peningkatan hasil proses pembuatan puding pisang melalui pendekatan quantum teaching bagi anak tunagrahita ringan. 3. Mengambil kesimpulan penarikan kesimpulan merupakan analisis lanjutan dari reduksi data, dan display data sehingga data dapat disimpulkan dan peneliti masih berpeluang untuk menerima masukan.

\section{Hasil Penelitian dan Pembahasan Hasil Penelitian}

Hasil penelitian digunakan untuk menjawab pertanyaan penelitian yang diajukan pada bab I, yaitu Bagaimanakah proses meningkatkan keterampilan membuat puding pisang $\mathrm{j}$ melalui pendekatan quantum teaching anak tunagrahita ringan kelas tata boga?, dan Apakah keterampilan membuat puding pisang pada anak tunagrahita ringan dapat ditingkatkan dengan menggunakan pendekatan quantum teaching?.

Pada siklus I peneliti memberikan tindakan dalam pembelajaran keterampilan proses pembuatan puding pisang melalaui pendekatan quantum teaching. Adapun bentuk kegiatan yang direncanakan dalam siklus I adalah membuat rencana pelaksanaan pembelajaran, menyiapkan video pembelajaran, mengembangkan lembar observasi, format evaluasi dan melihat perkembangan hasil belajar anak dalam proses pembuatan puding pisang. Pemberian tindakan pada siklus I ini dilakukan empat kali pertemuan, kemampuan anak pada siklus I dapat dilihat pada grafik dibawah ini : 


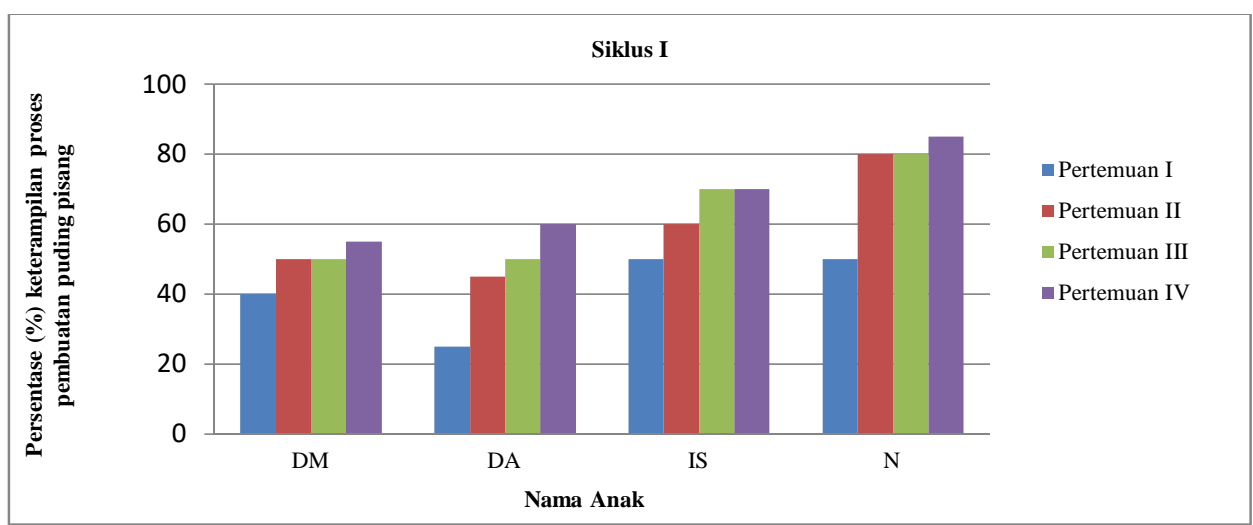

Grafik 1. Hasil tes kemampuan proses pembuatan puding pisang melalui pendekatan quantum teaching siklus I

Berdasarkan data yang diperoleh dari empat pertemuan, anak sudah mengalami peningkatan setelah diberikan tindakan melalui pendekatan quantum teaching. Namun hasil yang didapat oleh anak masih belum maksimal, oleh sebab itu, kesepakatan antara peneliti dan guru kelas agar dilanjutkan ke siklus II. Hal ini bertujuan supaya anak mampu melakukan proses pembuatan puding pisang.

Pemberian tindakan terhadap kemampuan proses pembuatan puding pisang pada siklus II dimulai dari membuat rencana pelaksanaan pembelajaran, menyiapkan video pembelajaran. Membuat lembar observasi dan format evaluasi yang digunakan untuk menilai kemampuan proses pembuatan puding pisang.

Siklus II dilakukan empat kali pertemuan. Perbedaan siklus I dengan siklus II terletak pada langkah-langkah menghias puding pisang. Hasil persentase kemampuan siswa diilhat dari grafik di bawah ini :

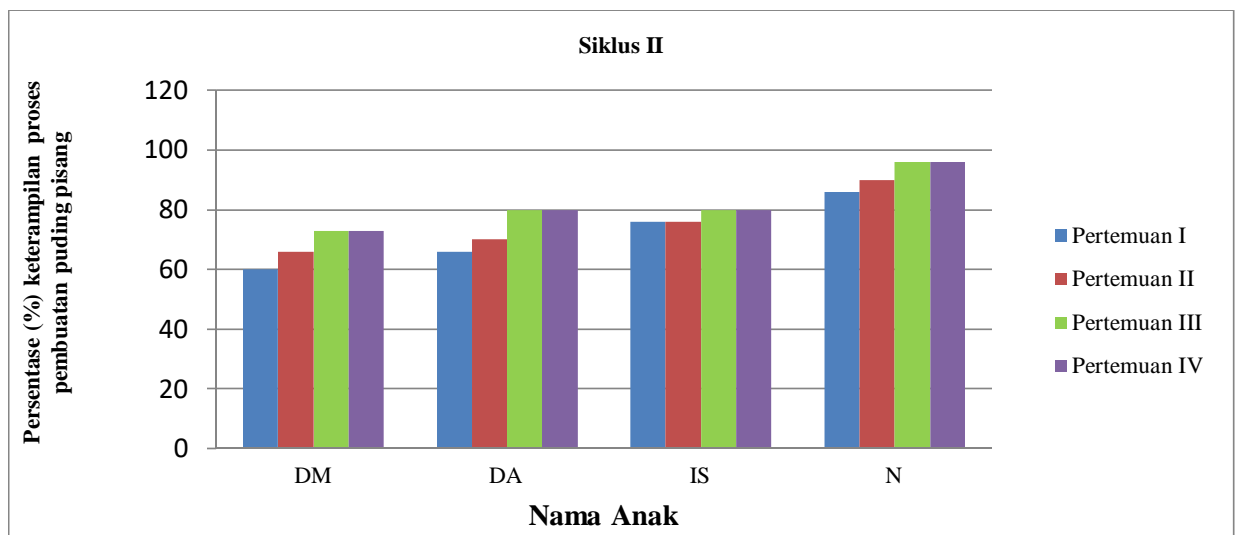

Grafik 2. Hasil tes kemampuan proses pembuatan puding pisang beserta menghias puding pisang melalui pendekatan quantum teaching siklus II

Berdasarkan siklus II hasil dari pengamatan peneliti bersama kolaborator dan anak juga telah dilakukan, maka selanjutnya dilakukan perenungan serta diskusi terhadap tindakan yang telah dilakukan. Peneliti dan kolaborator menyimpulkan bahwa pada umumnya kemampuan anak dalam proses pembuatan puding pisang disertai dengan menghias puding pisang telah meningkat, meskipun masih memerlukan bimbingan. Maka peneliti dan kolaborator sepakat untuk mengakhiri tindakan pada siklus II ini. Untuk memperjelas peningkatan kemampuan anak dari kemampuan awal sebelum diberi tindakan sampai ke siklus II dapat dilihat pada grafik berikut : 


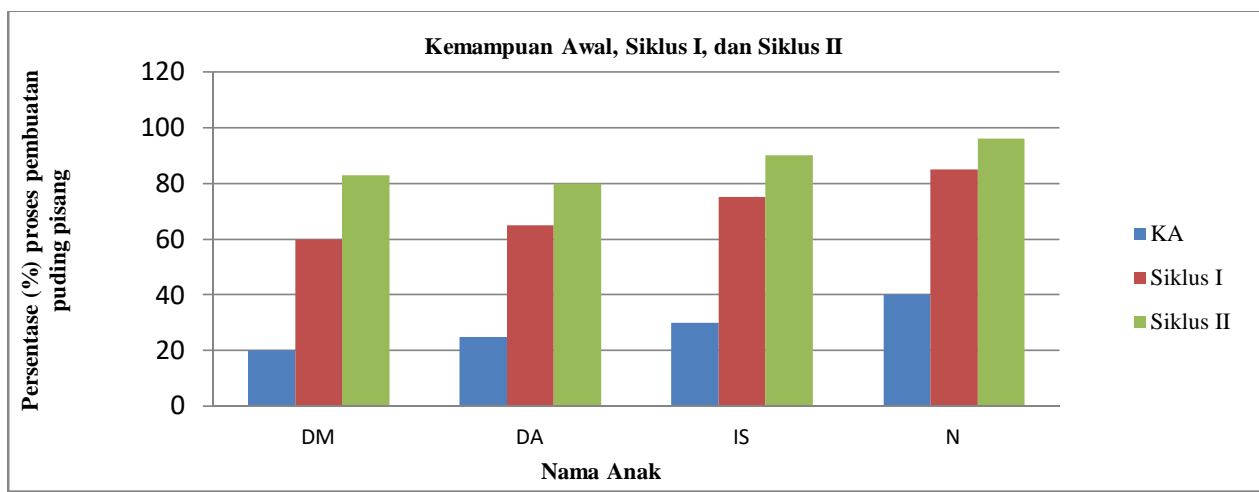

Grafik 3. Rekapitulasi hasil kemampuan awal, siklus I, dan siklus II.

Berdasarkan grafik di atas terlihat dari kemampuan awal, siklus I, siklus II, anak sudah mengalami peningkatan setelah diberikan tindakan melalui pendekatan quantum teaching.

\begin{tabular}{llcc}
\hline No & \multicolumn{1}{c}{ Aspek yang diamati } & $\begin{array}{c}\text { \% capaian siklus } \\
\text { I }\end{array}$ & Cara mengukur \\
\hline 1 & $\begin{array}{l}\text { Mempersiapkan dan menyebutkan alat-alat yang } \\
\text { dipergunakan dalam proses pembuatan puding } \\
\text { pisang }\end{array}$ & $57,5 \%$ & $\frac{\text { Jumlah Hasil anak }}{\text { Jumlah Pertemuan }}$ \\
\hline 2 & $\begin{array}{l}\text { Mempersiapkan bahan yang digunakan dalam } \\
\text { proses pembuatan puding pisang. }\end{array}$ & $55,84 \%$ & $\frac{\text { Jumlah Hasil anak }}{4}$ \\
& $\begin{array}{l}\text { Jumlah Pertemuan } \\
\text { pelaksanaan kegiatan proses pembuatan puding }\end{array}$ & $\frac{233,36}{4} \times 100 \%=55,84 \%$ \\
\hline 3 & $65,62 \%$ & $\frac{\text { Jumlah Hasil anak }}{\text { Jumlah Pertemuan }}$ \\
& $\frac{262,5}{4} \times 100 \%=65,62 \%$ \\
\hline
\end{tabular}

Tabel 4. Perolehan skor membuat puding pisang siklus I

Pemerolehan skor anak dalam proses pembuatan puding pisang siklus I ini dilihat anak dalam aspek yang dikur yaitu mempersiapkan alat, mempersiapkan bahan, dan pelaksanaan langkah-langkah membuat puding pisang, terlihat anak belum mencapai nilai KKM yaitu 67. Karena itu proses pembuatan puding pisang berlanjut ke siklus II. Sebagaimana terlihat

\begin{tabular}{clccc}
\hline No & \multicolumn{1}{c}{ Aspek yang diamati } & $\begin{array}{c}\text { \% capaian } \\
\text { siklus I }\end{array}$ & $\begin{array}{c}\text { \% capaian } \\
\text { siklus II }\end{array}$ & cara pemerolehan \\
\hline 1 & $\begin{array}{l}\text { Mempersiapkan dan menyebutkan } \\
\text { alat-alat yang dipergunakan dalam } \\
\text { proses pembuatan puding pisang }\end{array}$ & $57,5 \%$ & $76 \%$ & $\begin{array}{c}\text { Jumlah Hasil anak } \\
\text { Jumlah Pertemuan } \\
\frac{304}{4} \times 100 \%=76 \%\end{array}$ \\
\hline 2 & $\begin{array}{l}\text { Mempersiapkan bahan yang } \\
\text { digunakan dalam proses } \\
\text { pembuatan puding pisang. }\end{array}$ & $55,84 \%$ & $87,47 \%$ & $\begin{array}{c}\text { Jumlah Hasil anak } \\
\text { Jumlah Pertemuan }\end{array}$ \\
\hline 3 & $\begin{array}{l}\text { Pelaksanaan kegiatan proses } \\
\text { pembuatan pudding pisang. }\end{array}$ & $65,62 \%$ & $85,93 \%$ & $\frac{\text { Jumlah Hasil anak }}{\text { Jumlah Pertemuan }}$ \\
& & & $\frac{343,75}{4} \times 100 \%=85.93 \%$ \\
\hline 4 & $\begin{array}{l}\text { Mempersiapkan bahan yang } \\
\text { digunakan dalam proses menghias } \\
\text { puding pisang }\end{array}$ & $50 \%$ & $85,93 \%$ & $\frac{\text { Jumlah Hasil anak }}{\text { Jumlah Pertemuan }}$ \\
\hline
\end{tabular}




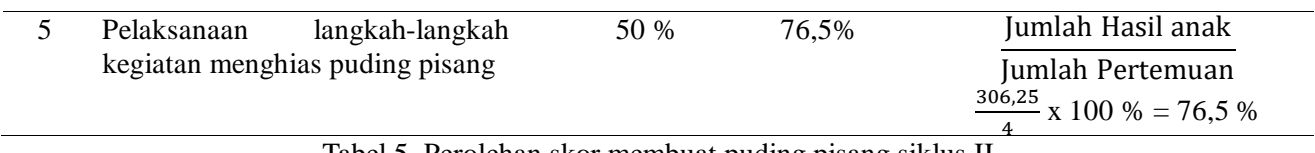

Tabel 5. Perolehan skor membuat puding pisang siklus II

Pemerolehan skor anak dalam proses pembuatan puding pisang siklus II ini dilihat anak dalam aspek yang dikur yaitu mempersiapkan alat, mempersiapkan bahan, dan pelaksanaan langkah-langkah membuat puding pisang, terlihat anak sudah mencapai nilai KKM yaitu 67. Karena itu proses pembuatan puding pisang telah terlihat meningkat pada siklus II.

\section{Pembahasan}

Hasil penelitian yang telah dilakukan pada siklus satu dan siklus dua adalah kemampuan masing-masing anak pada tiap siklus terlihat peningkatan. Ini menunjukkan bahwa anak tunagrahita ringan kelas tata boga dalam proses pembuatan puding pisang disertai dengan proses menghias puding pisang melalui pendekatan quantum teaching mengalami peningkatan.

Penerapan quantum teachuing dapat diterapkan untuk anak berkebutuhan tunagrahita sama pendapat ini sama dengan Agustina Gunaningsih Abdullah (2014) yang mengatakan penggunaan quantum teaching yang menerapkan TANDUR dalam kegiatan pembelajaran siswa juga diberikan pengalaman langsung yang pada dasarnya memang sesuai untuk anak tunagrahita ringan yang kemampuan berfikir abstraknya kurang. Dengan adanya pemberian pengalaman langsung dan penerapan TANDUR akan membantu anak tunagrahita dalam mengenal konsep bilangan. Sama hal nya dengan yang peneliti lakukan dengan adanya penerapan TANDUR anak lebih cepat memahami proses pembuatan puding pisang, karena ia lakukan bersama teman kelompoknya secara langsung anak melakukan proses pembuatan puding pisang.

Dampak positif yang ditimbulkan penggunaan pendekatan quantum teaching untuk meningkatkan keterampilan siswa dalam suasana belajar yang menyenangkan dikarenakan guru sebelum proses pembelajaran berlangsung mengajak semua siswanya untuk bernyanyi secara bersama-sama. Pendapat ini selaras dengan Dyah Ayu Poncowati (2010) dengan penerapan quantum teaching pelaksanaan kegiatan pembelajaran yang berlangsung dalam suasana yang menyenangkan. Pendapat tersebut, didukung oleh penelitian yang dilakukan oleh Agustina Gunaningsih Abdullah (2014) yang mengatakan penggunaan quantum teaching yang menerapkan TANDUR dalam kegiatan pembelajaran siswa dapat belajar dengan nyaman dan menyenangkan

Pemberian penghargaan memberikan kesan pada siswa bahwa usaha yang mereka laksanakan selama pembelajaran patut dihargai dan dirayakan. Pemberian penghargaan dikelas menjadikan siswa lebih bersemangat untuk berhasil dalam pembelajaran sehingga siswa termotivasi dalam belajar. Dengan demikian, dapat dikatakan bahwa penghargaan dapat meningkatkan motivasi belajar siswa, yang berpengaruh pula pada keberhasilan hasil belajar siswa. Pendapat ini sesuai dengan pendapat Bobbi DePorter (2014) yang menyatakan, sesuatu yang layak dipelajari maka layak pula dirayakan.

\section{Kesimpulan}

Keberhasilan pelaksanaan pembelajaran dikelas ditentukan oleh cara guru mengajar di kelas. Hasil penelitian ini menunjukkan bahwa dengan menggunakan pendekatan quantum teaching proses pembelajaran di kelas menjadi lebih baik dimana anak terlihat lebih aktif ketika proses pembuatan puding pisang, karena dilakukan dengan teman kelompok sehingga anak menjadi semangat ketika melakukan langkah-langkah pembuatan puding pisang. Sehingga hasil belajar selama delapan kali pertemuan terlihat ada peningkatan.

\section{Daftar Rujukan}

Abdullah, A. G., \& Mahmudah, S.(2014) Penggunaan Quantum Teaching Terhadap Kemampuan Mengenal Konsep Bilangan Siswa Tunagrahita Ringan Di Slb Ac Dharma Wanita Sidoarjo. Jurnal Ilmu Pendidikan (Akses 22/1/2018 11:45)

Arikunto, S. (2010). Prosedur Penelitian. Jakarta: Rineka Cipta

Badriyah, K. (2016). Peningkatan Pemahaman Konsep Penjumlahan 1 Sampai 10 Melalui Model Pembelajaran Quantum Teaching Pada Anak Tunagrahita Ringan Kelas Iii Slb Ma'arif Bantul. WIDIA ORTODIDAKTIKA, 5(4), 420-430. (Akses 22/1/2018 13:45)

Bobbi, D. (2010). Quantum Teaching. Bandung : Kaifa.

Depdiknas.(2009). Pedoman Sertifikasi Kompetensi Ketermpilan Khusus. Direktorat Jendral Pendidikan Luar Biasa 
Eveline, S. (2011). Teori Belajar dan Pembelajaran. Bogor : Ghalia Indonesia.

Marlina.(2017). Teacher's Attitude and Peer Acceptance to Children with Special Needs in Inclusive Primary Schools. Atlantis Press. 245-252. (Akses 22/1/2018 11:45)

Jumanta, H. (2016) Metodologi Pengajaran. Jakarta : Bumi Aksara.

Iskandar. (2011) Penelitian Tindakan Kelas. Jakarta : Gaung Persada (GP) Press.

Kunandar. (2012). Langkah Mudah Penelitian Tindakan Kelas Sebagai Pengembangan Profesi Guru. Jakarta : PT Raja Grafindo Persada.

Sugiyono. (2015). Metode Penelitian Pendidikan. Bandung : Alfabeta. 